\title{
RYBNÍK ZWEITÄMMIGE V HISTORICKÝCH A ARCHEOLOGICKÝCH PRAMENECH
}

\author{
JANA MAZÁČKOVÁ - PETR ŽAŽA
}

\begin{abstract}
Abstrakt: V povodi Kněžického potoka v lese Aleje je evidováno několik zaniklých vodohospodářských děl, která patři do extravilánu zdejšich ZSV (spolu s jejich hospodářským zázemím, doklady těžby a zaniklou komunikačni sití). Prvni písemné zmínky o vodohospodárských aktivitách v povodi Kněžického potoka dokumentuji zemské desky (14. století) a následně až urbár brtnického panství z roku 1538. Díky záchrannému archeologickému výzkumu byla zkoumána hráz zaniklé nádrže, která se nacházela v těsném sousedstvi ZSV Střenči. Doplňujicí se archeologické a písemné prameny upevňují předchozí predstavy o fungování panských ekonomik v průběhu pěti století a minimálně tři hlavnich majitelů panství.
\end{abstract}

Klíčová slova: ekonomika panství-rybniční hráz-hospodářské zázemí.

\section{The Zweitämmige fishpond in historical and archaeological sources}

Abstract: Several defunct waterworks have been identified in the catchment area of the Kněžický potok stream, in the Aleje forest, in the territory of several deserted medieval villages (together with their economic facilities, evidence of mining and a network of routes). The first written records about water management in the catchment area of the Knéžický potok stream come from the land register (14th century) and later from the urban register of the Brtnice demesne from 1538. Thanks to rescue archaeological research, the wall of a former reservoir located in close proximity of the deserted medieval village Strenčl was investigated. Archaeological and written sources have confirmed the hypothesis about the functioning of the demesne economy in over five centuries and under at least three owners.

Key words: economy of a demesne-pond wall-economic facilities.

\section{1 Úvod}

Mezi lety 2018 a 2019 proběhla série záchranných archeologických výzkumů v polesí Aleje (k. ú. Jestřebí u Brtnice, okr. Jihlava), které souvisely s aktivitami Lesů ČR při výstavbě retenčních nádrží na Kněžickém potoce. Stavební činnost proběhla v těsném sousedství ZSV Stř̌enčí a př́imo ovlivnila dvě staré hráze zaniklých vodních nádrží, jež jsou předmětem této studie. Výsledky těchto záchranných výzkumů bylo možné zařadit do již existujících poznatků na základě probíhajícího dlouhodobého povrchového, nedestruktivního výzkumu ZSV Střenčí, který je prováděn ÚAM FF MU (Mazáčková 2016).

Celý širší region Jihlavska a Brtnicka představoval v 11. a v průběhu 12. století pomezní hvozd, kterým procházely zemské stezky, a kolonizace sem pronikala až v poslední třetině 12 . století. $\mathrm{Na}$ východě se konsolidovalo zeměpanské území v okolí Přibyslavic a z jihu osídlení souviselo s fungováním Haberské stezky, na níž vznikaly tzv. etapové lokality jako další projev kolonizace (Hrubý a kol. 2014). Doklady rýžování zlata na katastrech mnohých vesnic poukazují na významnost této činnosti při kolonizaci a konstituování šlechtických panství v první třetině 13. století ve sledované oblasti. Vesnice založené a zaniklé v prostoru, nebo na okraji, současného polesí Aleje (ZSV Střenčí, Stančice a Zhořec) náležely do majetků zeměpanských a šlechtických rodů (Ranožířovci) a církevních institucí (předpokládané působení kněžických premonstrátů v podobě nevzniklého proboštství Želivského kláštera, nebo vliv ženského kláštera v Dalešicích). Na základě archeologického materiálu mají všechny tři zmíněné zaniklé vsi doložitelné osídlení v první třetině 13. století, a to na základě nálezů tuhové keramiky zdobené radélkem. Obdobná keramika provází nejstarší horizonty osídlení ve Staré Jihlavě, Brtnici, Kněžicích, Panské Lhotě, Stř̌́žově nebo zaniklém Zhořci. Zaniklé Stř̌enčí leží v nadmořské výšce 590-605 m na terasách bezejmenné vodoteče s antropogenními relikty usedlostí, které jsou obráceny k jihu nebo k severu (obr. 1). Návesní prostor je silně podmáčen, se stopami po minimálně třech zaniklých vodních nádržích. Severní terasa a část 


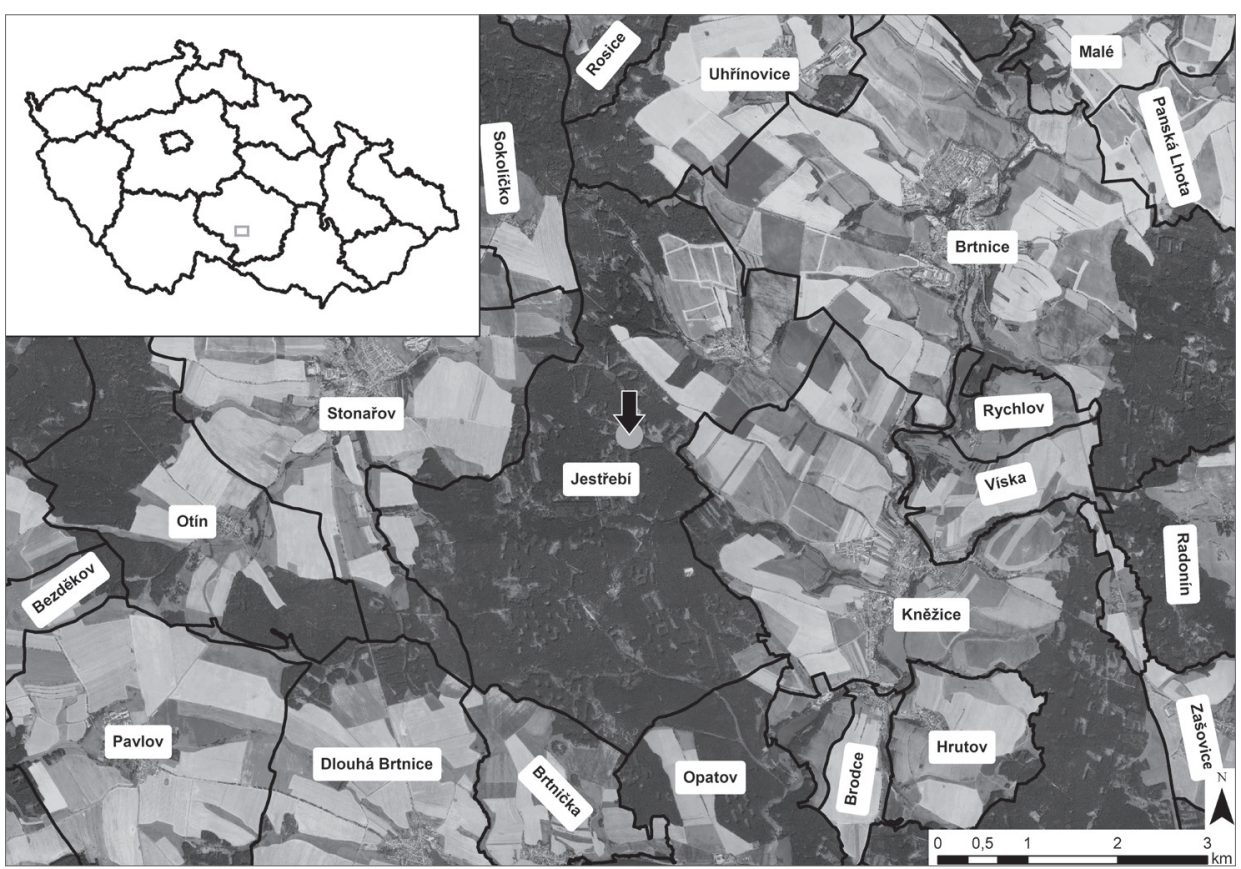

Obr. 1. Lokalizace ZSV Střenčí v Polesí Aleje (k. ú. Jestřebí u Brtnice), vyznačeno šipkou. Podkladová mapa wms ortofoto ČúZK.

Abb. 1. Mit Pfeil gekennzeichnete Lokalisierung der mittelalterlichen Dorfwüstung Střenčí in Polesí Aleje (Katastergebiet Jestř̌bí u Brtnice). Kartenunterlage WMS Orthofoto, Tschechisches Amt für Landesvermessung und Kataster.

vsi je poničena př́ijezdovou komunikací k soutoku Kněžického potoka a bezejmenné vodoteče procházející zaniklým Střenčím. Porost tvoří vzrostlý les, který byl ve východní části vykácen a byla zde založena lesní školka. Jižní terasa je pokryta mladým, již prořezaným smrkovým lesem.

\section{Písemné prameny}

První písemná zmínka o vsi uvádí k roku 1337 bratry Voka a Eberharda von Trench (CDM VII, 105 č. 134). Dále se Střenčí objevuje roku 1358, a to v zápise brněnské řady zemských desk. Ves je tou dobou již plně konsolidovanou a funkční jednotkou, a proto lez přepokládat její starší založení, které potvrzují hlavně archeologické prameny. Zemské desky ukazují Střenčí jako vesnici s lánovou soustavu rozdrobenou mezi několik vlastníků v letech 1358 až 1493, ale i v roce 1495, kdy se stala jako již pustá majetkem Brtnických z Valdštejna. Z písemných pramenů jsme rovněž informováni o zástavbě, a to od posledního desetiletí 14. století, kdy se v roce 1390 objevuje tvrz spolu se dvorem, v roce 1420 Kamprlovský dvůr a později dvůr Černého Ondřeje (ZDB VII, 199 č. 902). Po Střenčí se píší jak majitelé tvrze, např́ílad roku 1407 Dobeš ze Trenče, tak majitelé Kamprlovského dvora, Jindřich v roce 1415, nebo majitelé dvora Černého Ondřeje (ZDB IX, 255 č. 41, 42, 43; ZDB XI, 292 č. 63; ZDB XII, 355 č. 420).

Pokročilé rozdrobení vsi mezi různé vlastníky v 60 . letech 14 . století vylučuje možnost, že by byl Ješek zmiňovaný roku 1358 jediným majitelem vsi. Ten v roce 1361 přenechává, spolu s bratrem Vernušem, dvůr své ženě Zdence za 30 kop (ZDB IV, 48 č. 64). Podobných převodů střenčských majetků je doložena v zemských deskách celá řada. Poslední známou osobou píšící se po vsi je Barbora z Třenče (1493; KPb IV, 498 č. 520). Rod ze Střenčí se dělil o tvrz poprvé uvedenou roku 1390 (ZDB VII, 199 č. 902) a roku 1409 již pustou (ZDB X, 282 č. 25), další sídlili na svobodných dvorech (Měŕínský 1988, 33). 
Jako osedlá se ves naposledy zmiňuje v půhonu z roku 1447 (KPb III, 366 č. 364). Jako pustá se objevuje v dalším půhonu z roku 1466 (KPb IV, 218 č. 940b). Tato situace neodpovídá starším závěrům se zanikáním vsí na Brtnicku, které mělo souviset s tažením Matyáše Korvína na Moravu v roce 1468, konkrétně během obléhání Třebíče, nebo s tažením vedeným z Rakouska roku 1467, jež mohlo zasáhnout i Jihlavsko (Slavík 1893, 25; Matějek 1954, 222; Navrátil 1985, 82-85). Ještě roku 1495 se píše již zmiňovaná Barbora ze Střenčí, která je dědičkou dvora Černého Ondřeje. Zdejší majetky skupují Valdštejnové, kteří až k roku 1495 vlastní kompletní pustou ves Střenčí a její ekonomické zázemí (ZDB XVI, 72 č. 262). Hospodářský záměr Valdštejnů spočíval v pronajímání získané, ale neobdělávané půdy hospodářum z okolních sídel. V urbáři brtnického panství z roku 1538 se zakupují na střenčské pozemky ve formě polí, úhoru, luk a palouku sedláci z Brtnice, Jestřebí, Kněžic, Stonařova nebo Vísky. Celkem 54 osob platilo za pozemky na pustém Střenčí 7 kop a 19 grošů (MZA, fond G 10, inv. č. 638, fol. 111-113). Až se změnou majitelů panství po roce 1624 dochází k novému způsobu hospodaření s pozemky zaniklých osad. Ty nejsou nadále pronajímány, prostor Střenčí byl zalesněn. Středověká rybniční kaskáda byla ale nadále využívána až do poloviny 19. století, jak bude dále doloženo v textu. Velkou změnu znamenala na počátku 19. století výstavba loveckého zámečku Aleje, který byl vybudován v centru obory, od něj se paprsčitě rozbíhá sedm cest, které přetvořily původní komunikační schéma v prostoru.

\section{Rybniční soustava na ZSV Střenčí}

V okolí vesnice Střenčí (existence 13.-15. století) se rybníky vyskytovaly ještě před samotným zánikem vsi. Lze je doložit písemnými zmínkami v kombinaci s archeologickou terénní prospekcí a kartografickými prameny. Dvě až tři vodní nádrže lze rekonstruovat na bezejmenné vodoteči protékající intravilánem vesnice se dvěma výrazně dochovanými relikty hrází (obr. 2:8, 10). Písemné prameny potvrzují k roku 1390 existenci rybníků. Albert řečený ze Zaharhan spolu s Albertem z Mladyeyowicz zakupují od Buzka ze Střenčí dvůr spolu s rybníky, potoky, lesy a loukami (ZDB VII, 199 č. 902). V dalších intabulacích z let 1409, 1417 a 1420 je vždy prodávána polovina rybníku, spolu s dalšími majetky (ZDB X, 282 č. 25; ZDB XI, 315 č. 407; ZDB XII, 330 č. 53). Zvětšováním a scelováním statků kolem Brtnice si tak v druhé polovině 15 . století Valdštejnové vytvořili mimo jiné i předpoklady k poměrně rozsáhlému rybničnímu podnikání. V urbáři brtnického panství vzniklém kolem roku 1538 je uveden soupis 86 rybníků. K rybníkům na Kněžickém potoce nebo na jeho středním a dolním pravobřežním přítoku patrně podle tohoto soupisu náleží Rybniczek na Strzenczy, Rybnik druhy nad sylniczy, Rybnik trzeti na Strzenczy, Rybnik cztrvty na Strzenczy, Rybnik paty na Strzenczy, Rybnik wstekly na Strzenczy, Rybnik na sylniczy (obr. 2:1-7), Rybnik u tvrze na Strzenczy, Rybniczek druhy nad tim (obr. 2:8, 10; MZA, fond G 10, inv. č. 638, fol. 117-118).

Počet rybníků uváděných $\mathrm{v}$ urbáŕích vykazuje kontrast mezi písemnými prameny z 14.-15. a ze 16. století (Matějek 1956, 45). V urbáŕi brtnického panství z roku 1538 je uvedeno devět rybníků, které nesou označení přímo po zaniklém Střenčí (např. Rybnik u tvrze na Strzenczy), nebo názvem na takový rybník odkazují (např. Rybniczek druhy nad tim), zatímco ve starším období se o přssném počtu rybníků nedozvídáme nic. Kaskáda rybníků na Kněžickém potoce začíná pravděpodobně u hráze s parc. č. 843. Tento relikt lze ztotožnit s rybníkem pojmenovaným jako Rybniczek na Strzenczy. Poslední v kaskádě by byl rybník dnes pojmenovaný jako Ovčák, ale v Urbáři brtnického panství se patrně jedná o Rybnik na silniczy. Využití hráze jako komunikace dokládají i úvozy zaříznuté do svahů a směřující k hrázi (obr. 2:7). Na vodoteči procházející prrímo Střenčím byl vybudován Rybnik u tvrze na Strzenczy, který ve výpisu urbáře následuje po údaji Rybnik na silniczy. Druhou nádrží byl urbářem zmiňovaný Rybniczek druhy nad tim. V tomto případě je otázkou, zdali se jedná o po proudu níže položenou nádrž se setřelou hrází (obr. 2:9), nebo o zaniklou vodní nádrž s hrází, která nese parc. č. 854 na indikační skice z roku 1835 (obr. 2:10). Vizuálně odpovídá názvu spíše první možnost a zároveň využití hráze jako komunikační spojnice mezi severním a jižním břehem vodoteče a vesnice. Urbář panství též 


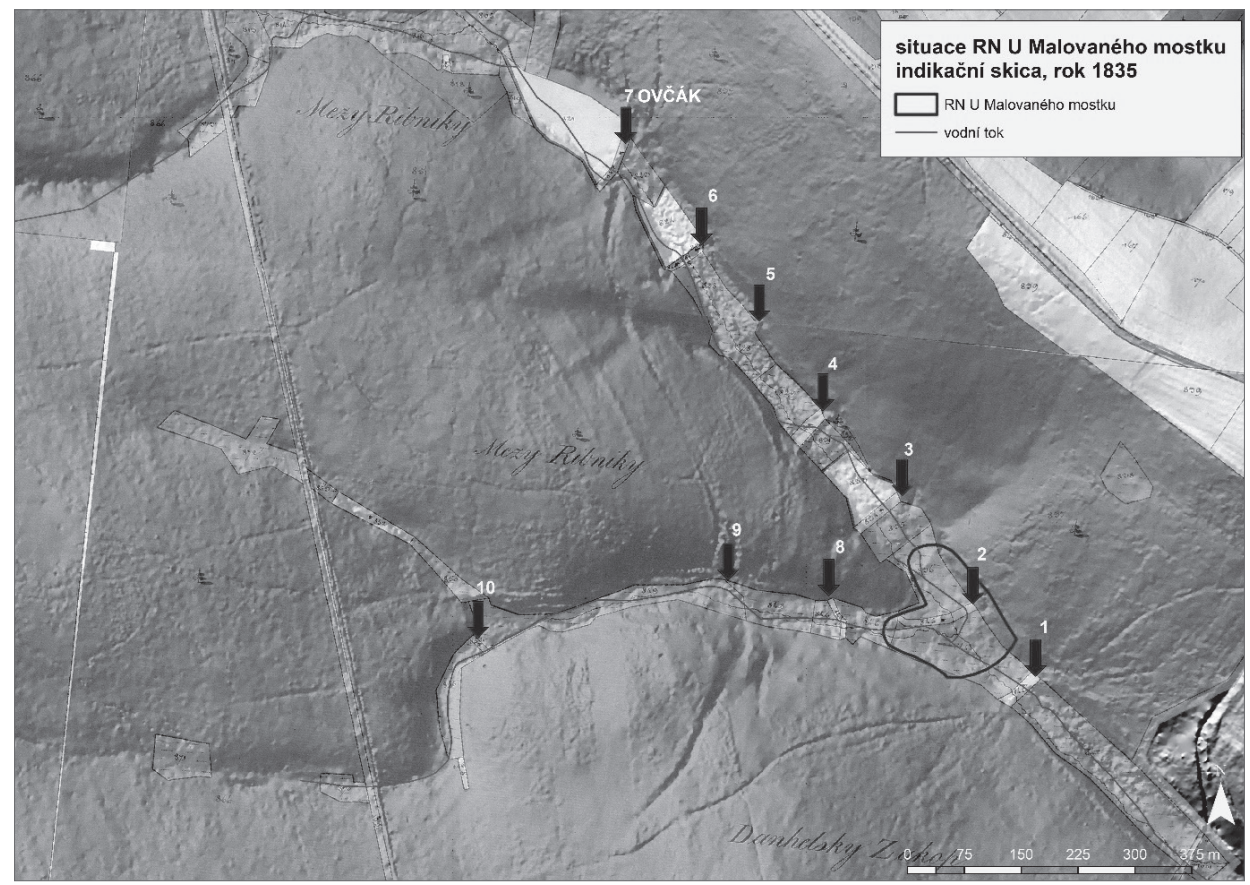

Obr. 2. Výřez z povinného císařského otisku indikační skici katastru Jestřebí u Brtnice (Haslitz), 1835, součást collaltovského panství s centrem v Brtnici. Zaniklé hráze vodních děl označeny černou šipkou. Podloženo digitálním modelem terénu.

Abb. 2. Ausschnitt aus dem Kaiserpflichtexemplar der Indikationsskizze des Katasters Haslitz bei Pirnitz (Jestřebí u Brtnice), 1835, Bestandteil der Herrschaft Collalto mit Zentrum in Brtnice. Untergegangene Dämme der Wasserbauwerke mit schwarzem Pfeil gekennzeichnet. Unterlegt mit einem digitalen Geländemodell.

zmiňuje množství vsádky ryb do jednotlivých rybníků, a to od jedné do 15 kop plodů. Jen do třech rybníků se sázela jedna kopa plodů na výrost, šlo o Rybniczek na Strzenczy, Rybnik u tvrze na Strzenczy a Rybnik druhy nad tim. (obr. 2:1, 8, 9 nebo 10). Z tohoto vybočoval pouze Rybnik druhy nad sylniczy, do něhož se sázelo 15 kop plodů (MZA, fond G 10, inv. č. 638, fol. 117).

Př́tomnost rybníků v okolí Střenčí dokládají mimo písemné prameny i novověká mapování. Na I. vojenském mapování z let 1764-1768 se v prostoru nebo v blízkosti lokality Střenčí vyskytují čtyři rybníky na Kněžickém potoce, které jsou zaznačeny severně proti proudu Kněžického potoka, nejseverněji položený rybník je patrně Ovčák, další tři jsou jižně od něho. Nejjižněji položený lze identifikovat s rybníkem označeným urbářem z roku 1538 jako Rybnik nad sylniczy. Komunikační schéma v jeho blízkosti zobrazuje cestu vedoucí ze Stonařova do Kněžic. Mapa brtnického panství z roku 1822 zachycuje obdobnou situaci jako I. vojenské mapování. Zachycena je kaskáda čtyř rybníků pod označením čísly 20-23. Jména rybníků jsou od č. 20-Zweitämmige, 21 - Korandowski, 22 - Seitowati, 23 - Haslitzer neue (obr. 3; MZA, fond F 16, mapa 1033). Rybník Zweitämmige je vodní nádrž, jejíž hráz má právě parc. č. 845. Pod soutokem Kněžického potoka s bezejmenným dolním pravobřežním přítokem, na kterém leží vodní nádrž Jezírko, jež v mapě nese č. 24 a stejné označení, je rybník s č. 19 - Ibser. Indikační skica katastru Jestřebí u Brtnice (Haslitz) z roku 1835 ukazuje rybník s hrází parc. č. 845 vypuštěný. Až porostová mapa z roku 1856 zobrazuje napuštěný rybník s hrází parc. č. 845 a celou zbylou kaskádu rybníků až k rybníku Ovčák, tedy v roce 1822 označené rybníky Zweitämmige, Korandowski, Seitowati a Haslitzer neue (Ovčák). Mapy panství Brtnice prokazují využívání vytvořené rybniční kaskády

1 Neboli ,dvojhrázný“, což může být dáno tím, že do něj natékaly dva potoky, či prostě faktem, že se rybník nacházel v kaskádě rybníkủ. 


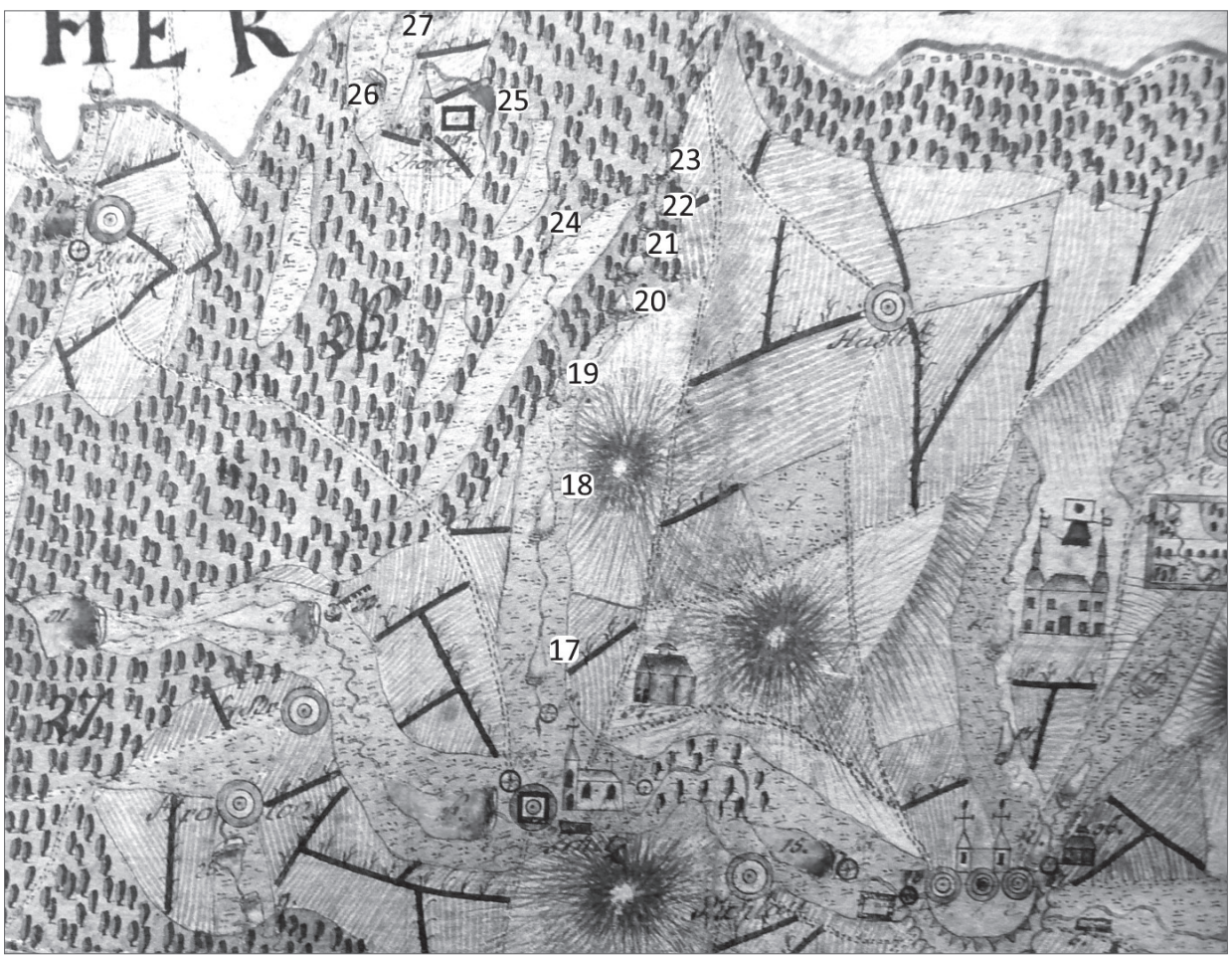

Obr. 3. Mapa brtnického panství z roku 1822 (MZA, fond F 16, mapa 1033, výřez Zhořec - Jestřebí - Kněžice). Nejblíže soutoku Kněžického potoka s bezejmenným pravobřežním přítokem je rybník s č. 20 a názvem Zweitämmige.

Abb. 3. Karte der Herrschaft Pirnitz von 1822 (Mährisches Landesarchiv, Bestand F 16, Karte 1033, Ausschnitt Zhořec- Jestř̌ebí - Kněžice). Dem Zusammenfluss des Baches Kněžický potok mit einem namenlosen rechtsufrigen Zufluss am nächsten gelegen ist Teich Nr. 20 mit dem Namen Zweitämmige.

minimálně od dob sestavení brtnického urbáře z roku 1538, kde je rybník Zweitämmige označen jako Rybnik nad sylniczy. Mladší mapování včetně III. vojenského mapování z roku 1875 již rybník s hrází parc. č. 845 napuštěný nezobrazují. Po polovině 19. století patrně došlo k omezení rybníkářství a postupně zbylé dva rybníky pod rybníkem Ovčák zanikají.

\section{Archeologický výzkum hráze rybníka Zweitämmige}

Plánovaná vodohospodářská stavba Retenční nádrž (dále RN) U Malovaného mostku zaplavila ve své vodní ploše zachovaný relikt hráze středověkého rybníka (hráz: parc. č. 845; zatravněná plocha původního rybníka: parc. č. 836, k. ú. Jestřebí u Brtnice; obr. 4). Hráz přehrazuje údolí Kněžského potoka v místě soutoku Kněžského potoka a bezejmenné pravobřežní vodoteče, která protéká zaniklou středověkou vsí Střenčí. Nadzemní i zahloubené antropogenní relikty byly rozpoznány pouhou vizuální prospekcí terénu stávajícího lesního prostředí bez využití jiných metod odhalujících archeologické struktury pod zemí. Doposud nejblíže dokumentovaný nadzemní dvoudílný objekt (mlýnice) v zaniklém Střenčí je vzdálen 16 m od hranice vodní plochy RN U Malovaného mostku a nachází se v inundaci bezejmenné vodoteče. Nejbližší archeologický artefakt se nacházel jen $8 \mathrm{~m}$ od hranice retenční nádrže (obr. 5). Další antropogenní relikty byly zachyceny na hraně jižní terasy bezejmenné vodoteče, východně od dokumentovaných objektů, vzdálených od záplavy jen 9 m. Dále východně na hraně se mohlo nacházet pokračování zaniklého Střenčí, nebo jeho přímé hospodářské zázemí, které představují ale i relikty obou zaniklých vodních děl s hrázemi parc. č. 845 a 843. 


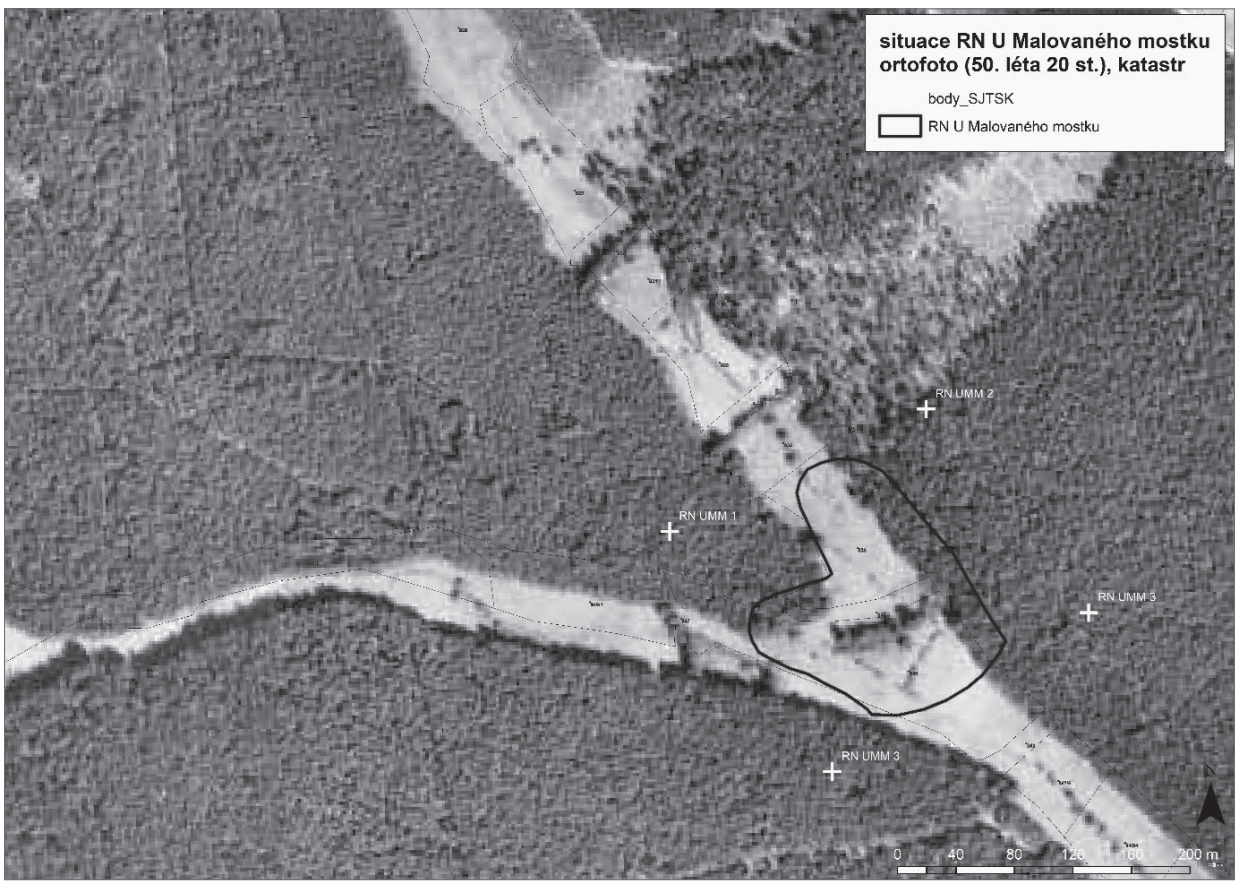

Obr. 4. Situace RN U Malovaného mostku. Ortofoto z roku 1953 ukazuje sečené louky v povodí obou vodotečí a zalesněné plochy zaniklých hrází včetně zaniklé hráze parc. č. 845. Podklad archivní ortofoto, dostupné z: https://kontaminace.cenia.cz/.

Abb. 4. Situation des Rückhaltebeckens U Malovaného mostku. Das Orthofoto aus dem Jahr 1953 zeigt gemähte Wiesen im Flussgebiet beider Wasserläufe und waldbedeckte Flächen der untergegangenen Dämme einschließlich des untergegangenen Dammes Parzellennr. 845. Archiviertes Orthofoto, verfügbar unter: https://kontaminace.cenia.cz/.

Záchrannému archeologickému výzkumu předcházela geofyzikální prospekce provedená v roce 2015 ÚAM FF MU Brno (obr. 6). Geofyzikální měření mělo prokázat archeologický potenciál území před stavbou RN U Malovaného mostku. Zaniklá středověká vesnice Střenčí je zkoumána nedestruktivním výzkumem, a to povrchovou prospekcí a geodetickým zaměřením od roku 2012, taktéž ÚAM FF MU Brno. Geofyzikálně měřená plocha 3, položená jižně od hráze parc. č. 845 , je v místě původního dna zaniklé vodní nádrže s hrází parc. č. 843. Tato plocha byla v průběhu 90. let 20. století a na počátku 21. století využívána jako místo letních táborů. Archeologicky zajímavé anomálie zde nelze identifikovat. Jedinými anomáliemi jsou drobné vysoce magnetické bipóly vytvořené poztrácenými železnými předměty. V prŕípadě existence letního tábora zde můžeme předpokládat výrazné zanesení odpadem (stanové kolíky, hřebíčky, kování a podobně).

V rámci záchranného archeologického výzkumu v letech 2018-2019 proběhlo zaměření zaniklého vodohospodářského díla a jeho nejbližšího okolí, dokumentace odhaleného zatrubnění výpusti rybníka, dokumentace kamenných struktur v rybničním sedimentu a prospekce sedimentu rybníka. V rámci stavebních prací bylo prohloubeno koryto Kněžského potoka v délce protékající stavbou, a to i v místě proražení hráze (původní výpusti). Při rozšíření a prohloubení odtokového koryta pro vodu Kněžského potoka byl dokumentován rybniční sediment. Rybniční sediment představovala drnová vrstva, která přecházela v sediment v_01, ten nasedal na př̀evážně jílovitou vrstvu probarvenou díky př́itomnosti organického materiálu do šeda. Vrstva v_02 překrývala 1-1,5 m mocný černý půdní horizont, který mohl být dokladem vzniku drnové vrstvy při některém vysušení rybníka. Pod touto vrstvou ležela taktéž homogenní vrstva v_04 př́evážně jílovitého charakteru probarvená do šeda. Podrobný pedologický popis byl proveden u sondy 1/18, 


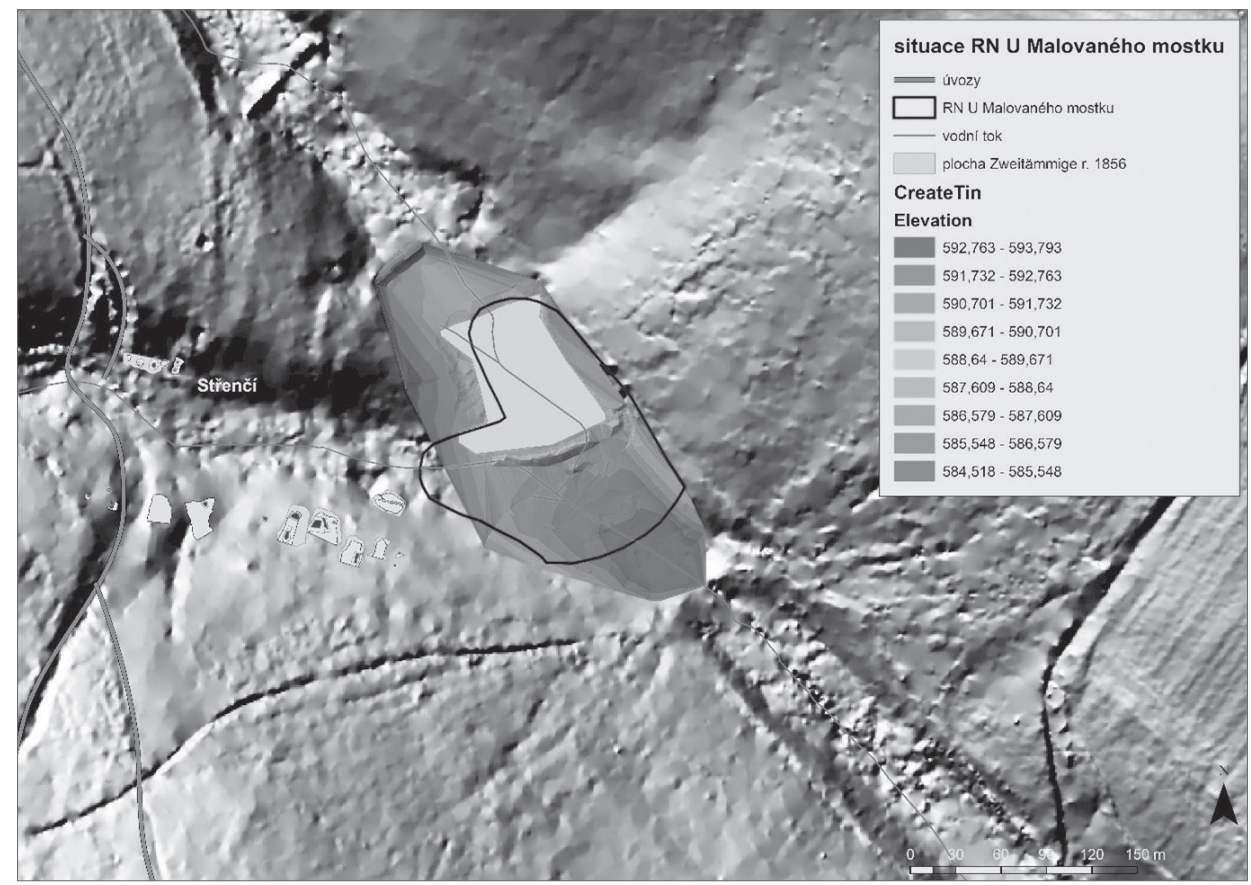

Obr. 5. Pohled na celkovou situaci zaměřených antropogenních reliktů v okolí RN U Malovaného mostku, zaniklá vesnice Střenčí a hráz rybníka Zweitämmige a jeho plocha $6421 \mathrm{~m}^{2} \mathrm{k}$ roku 1856 . Zdroj archiv autorů.

Abb. 5. Blick auf die Gesamtsituation der vermessenen anthropogenen Relikte in der Umgebung des Rückhaltebeckens U Malovaného mostku, Dorfwüstung Střenčí und Damm des Teiches Zweitämmige und seine Fläche von $6421 \mathrm{~m}^{2} \mathrm{im} \mathrm{Jahr}$ 1856. Quelle Archiv der Verfasser.

která byla odebrána z rybničního dna parc. č. 836 (tab. 1). Vrstvy hloubky 10/20-50 cm odpovídají vrstvě v_01 dokumentované od rozšsiřeného odvodového koryta potoka. V sondě 1/18 zachycená vrstva v hloubce 72-75 cm odpovídá vrstvě v_03.

V místě prokopnutí tělesa hráze došlo k záměrnému rozšíření staršího průrazu stavebníkem pro zvýšení odtoku vody. Při těžbě zeminy došlo k odhalení dřevěné konstrukce výpusti v podobě výpustní roury s dochovaným čapovým okem. Pozůstatek zatrubnění výpusti (délka $15 \mathrm{~m}$, šířka $0,4 \mathrm{~m}$ ) zaniklého středověkého rybníka ležel v potočním sedimentu a postupně byl překrýván sesuvem hrázního tělesa při východní straně průrazu hrází. Celá dřevěná struktura byla odkryta v původní poloze, nicméně působení místní vodoteče vymlelo původní hutněný materiál tělesa hráze a byl nahrazen potočními sedimenty. Dřevěná konstrukce byla vypreparována a vyzvednuta z potočního prostředí. Homogenní hutněná zemní hráz měla výšku $3 \mathrm{~m}$. Zatrubnění v délce $15 \mathrm{~m}$ bylo v patě hráze uchyceno pomocí více než sedmi kůlů. Čtyři další nebyly zachyceny in situ. Jednalo se o kůly o délce $40-50 \mathrm{~cm}$ a průměru $10-20 \mathrm{~cm}$. S největší pravděpodobností pocházely všechny kůly z místa původního tělesa hráze a zřejmě sloužily k upevnění zatrubnění do násypu hráze, čepová část předstupovala před těleso hráze o $2,8 \mathrm{~m}$ (obr. 7).

Vypouštěcí zařízení rybníků představuje v nejstarším období stavidlo a čap. Čapová (čepová) výpust je složena ze zátky kónického tvaru (obr. 8), která uzavírá výpustní otvor (čapové oko) v dřevěném výpustním potrubí. Výpustní otvor mohl být v některých případech doplněný o trubku nebo stavbu ústící na hladině (obr. 9:1). Výpust ohrazená zahrádkou, brlením, berlením, neboli česlovými stěnami, byla chráněna proti vniknutí nežádoucích ryb a pro zachycení splavenin. Brlení je umístěno před odběrný objekt a do napájecího koryta v místě vtoku do nádrže. Dále bývá brlení umístěno před vypouštěcím objektem a brání úniku ryb do toku pod nádrží. Takovéto 


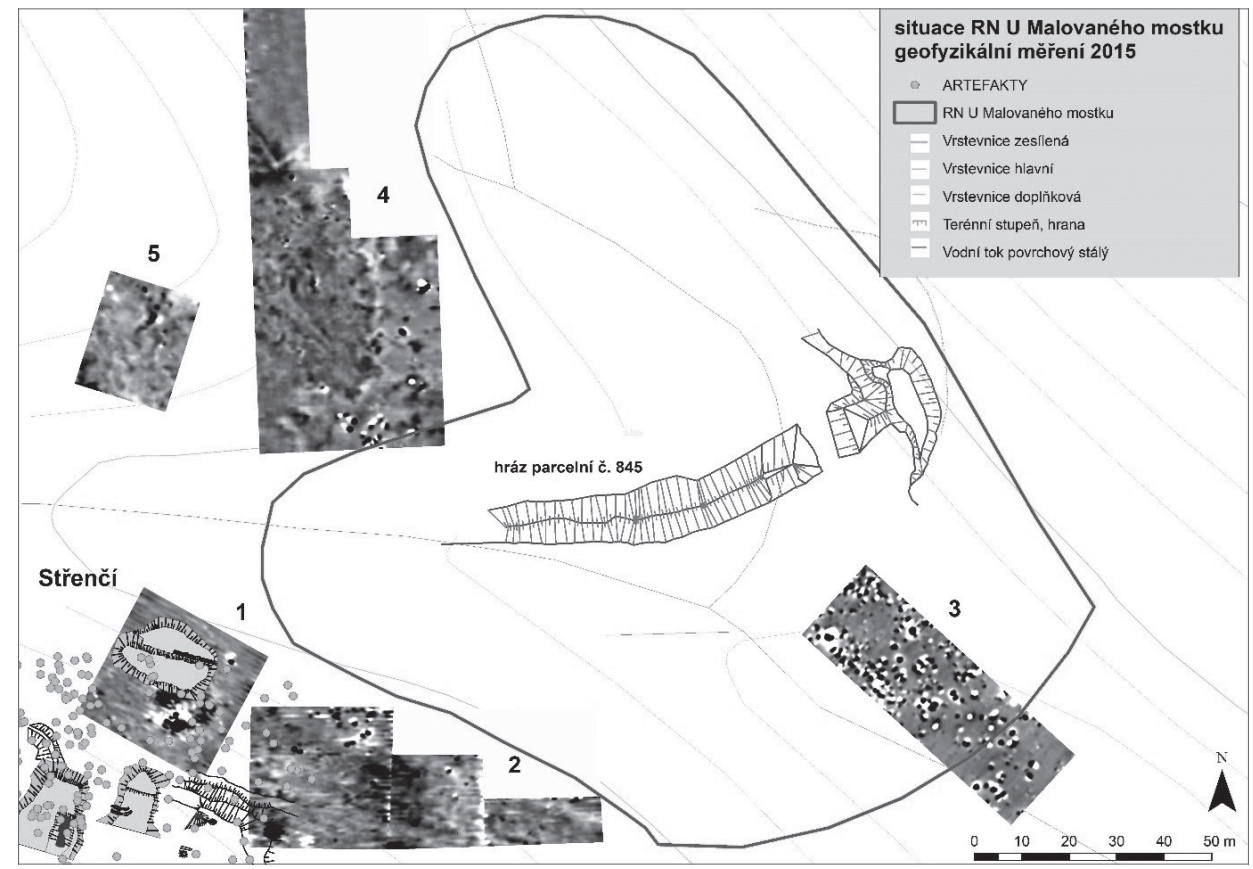

Obr. 6. Geofyzikální měření ploch 1-5 v souvislosti s výstavbou RN U Malovaného mostku, vztah hráze parc. č. 845, reliktů ZSV Střenčí, artefaktů získaných detektorovým průzkumem do roku 2018. Geofyzikální průzkum proběhl v kvadrantu o ploše $32066 \mathrm{~m}^{2}$. Zdroj archiv autorů.

Abb. 6. Im Zusammenhang mit dem Bau des Rückhaltebeckens U Malovaného mostku durchgeführte geophysikalische Messung der Flächen 1-5, Bezug des Dammes Parzellennr. 845, der Relikte der Dorfwüstung Střenčí, der durch Detektorsuche bis zum Jahr 2018 entdeckten Artefakte. Die geophysikalische Untersuchung erfolgte in einem Quadranten mit der Fläche von 32066 m²$^{2}$. Quelle Archiv der Verfasser.

Tab. 1. Sonda $1 / 18$ položená do rybničního sedimentu na parcele č. 836, k. ú. Jestřebí u Brtnice.

Tab. 1. Im Teichsediment auf Parzelle Nr. 836 im Katastergebiet Jestřebí u Brtnice gelegter Sondierschnitt 1/18.

\begin{tabular}{|c|l|}
\hline Hloubka $(\mathrm{cm})$ & Charakter vrstvy \\
\hline $0-10 / 20$ & A horizont \\
\hline $10 / 20-42$ & jílovitý písek, nesoudržný, šedý narezlý \\
\hline $42-50$ & jílovitý písek až písčitý jíl, soudržný, šedý narezlý \\
\hline $50-62$ & stř́dání vrstev jíl-písek, jíl-písek, prachový jíl \\
\hline $62-66$ & prachovitý písčitý jíl \\
\hline $66-72$ & jemný štěrk a hrubý písek, namíchaný s prachovito-jílovitým sedimentem (zaoblený) \\
\hline $72-75$ & jíl písčitý šedý \\
\hline $75-79$ & hrubý písek se sedimentem šedý \\
\hline $79-100$ & jíl píšcito-prachovitý na konci světlejší \\
\hline
\end{tabular}

dřevěné konstrukce nebyly $\mathrm{v}$ okolí dřevěné výpustní roury zachyceny $\mathrm{v}$ prostoru návodní ani vzduchové strany hráze. Samotná výpustní roura se skládá ze dvou spojených koryt vydlabaných do kmenů nebo ze spodního koryta překrytého fošnou. $V$ tomto střenčském prrípadě se jedná o konstrukci vytvořenou z kmene jednoho stromu, který je podélně rozrríznutý a vydlabaný. Spojení obou koryt je provedeno pomocí dvouramenných plochých skob, které kopírovaly tělo 


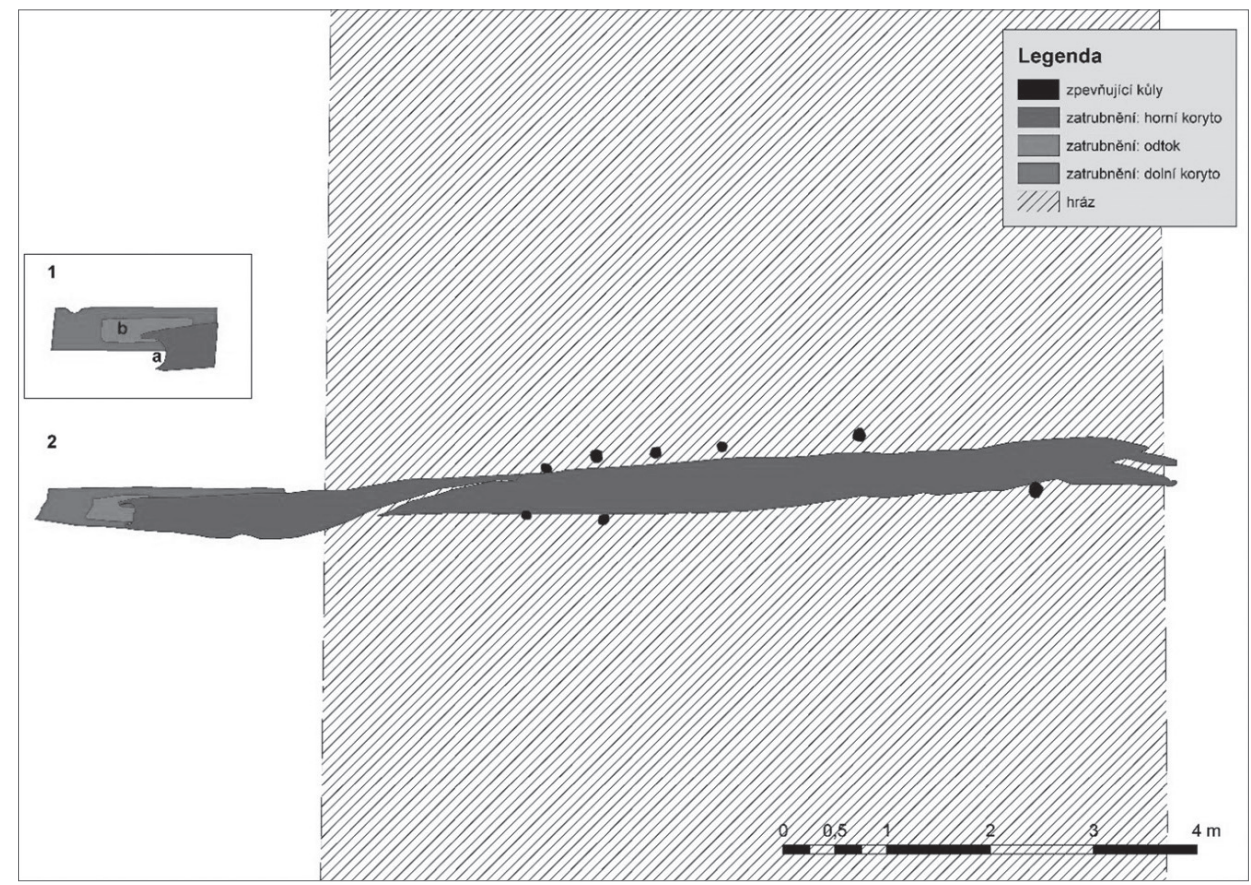

Obr. 7. Výpust na čep a výpustní roury. 1a - spodní koryto s odtokem; 1 b - čepový otvor (čapové oko) a poškozené horní koryto s odlomenou částí čepového oka; 2 - výpustní roura a její upevnění v tělese hráze pomocí kủlủ. Zdroj archiv autorů.

Abb. 7. Zapfenauslass und Auslassrohre. 1a - untere Rinne mit Ablauf; 1b - Zapfenöffnung (Zapfenauge) und beschädigte obere Rinne mit abgebrochenem Zapfenaugenteil; 2 - Auslassrohr und seine Befestigung im Dammkörper durch Pfähle. Quelle Archiv der Verfasser.

kmenu. Kramle byly umístěny po obvodu spoje a zároveň v průřezu kmenu u čapového oka. Zde byly dvě skoby, které zajišt’ovaly spojení dlabané roury z jednoho kusu kmene.

Část dřevěné výpusti z náběhové strany rybníka byla za pomoci bagru oddělena od zbytku zatrubnění. Jedná se o jedinou část zatrubnění, která nese jasné stopy opracování. Po vyzvednutí z koryta vodoteče byla celá konstrukce fotograficky zdokumentována (obr. 10). Výpustní rouru tvořily dvě části, které byly spojeny minimálně čtyřmi dvojramennými skobami (kramle), další nebyly identifikovány. Přesto není vyloučeno, že jejich počet byl větší. Po vyzvednutí byl odebrán vzorek vrstvy pod výpustní rourou. Zajištovací kůly byly vyzvednuty a nakonzervovány. Vzorky vrstvy z tělesa hráze nebyly odebrány kvůli nízké teplotě (půda byla zmrzlá). Dendrochronologické datování a dendrologické určení zatrubnění rybníka prokázalo využití jedle (41 letokruhů), která byla skácena 1694/1695 (Kyncl 2019, číslo vzorku Y7657). Datace konstrukčního prvku poukazuje na collaltovské hospodaření v rybníkářství a potřebnou úpravu starých hrází rybníků zřízených na Kněžském potoce.

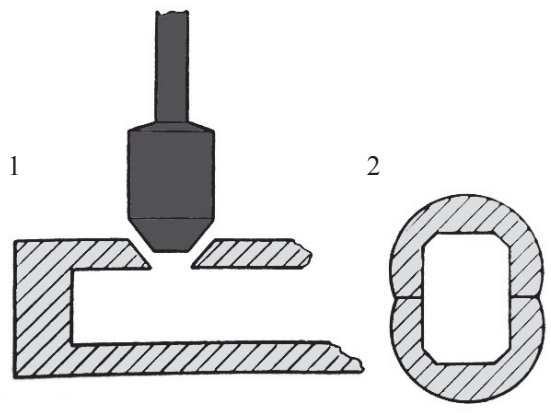

Obr. 8.1 - čep a zatrubnění výpusti; 2 - profil dřevěné trouby složené ze dvou koryt. Podle Nový a kol. 1974, 367, 189 b. Abb. 8.1 - Zapfen und Verrohrung des Auslasses; 2 - Profildarstellung des aus zwei Rinnen bestehenden Holzrohrs. Nach Nový a kol. 1974, 367, 189b. 


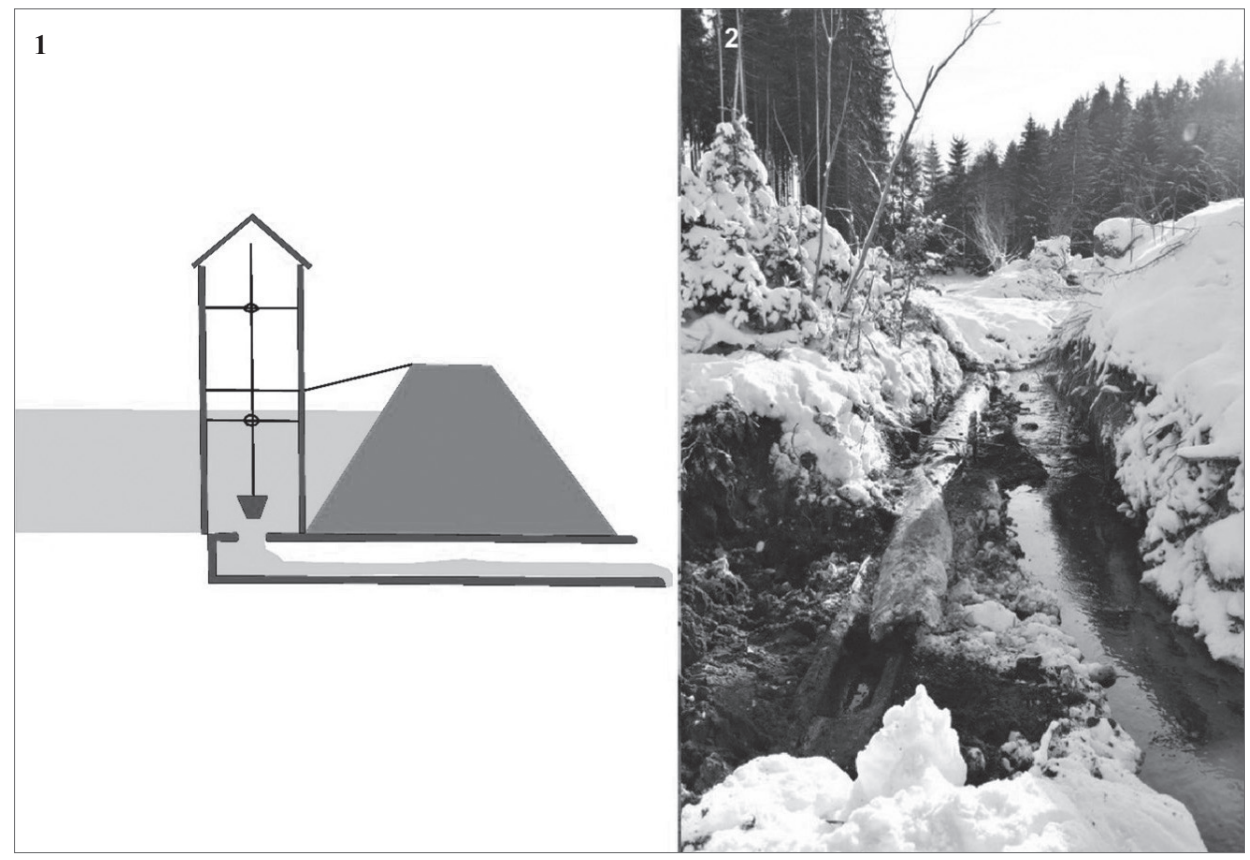

Obr. 9.1 - výpust Adolfka, rybník Rožmberk. Zdroj http://www.taggmanager.cz/poi_images/2145/3990.jpg; 2 - dřevěné zatrubnění - výpust rybníka s proraženou hrází parc. č. 845, k. ú. Jestřebí u Brtnice (RN U Malovaného mostku). Foto archiv ÚAM FF MU.

Abb. 9. 1 - Auslass Adolfka, Rožmberk-Fischteich. Quelle http://www.taggmanager.cz/poi_images/2145/3990.jpg; 2 - Verrohrung aus Holz - Teichauslass mit Dammdurchstoß Parzellennr. 845, Katastergebiet Jestř̌ebí u Brtnice (Rückhaltebecken U Malovaného mostku). Foto Archiv Institut für Archäologie und Museologie der Phil. Fak. der Masaryk-Universität.

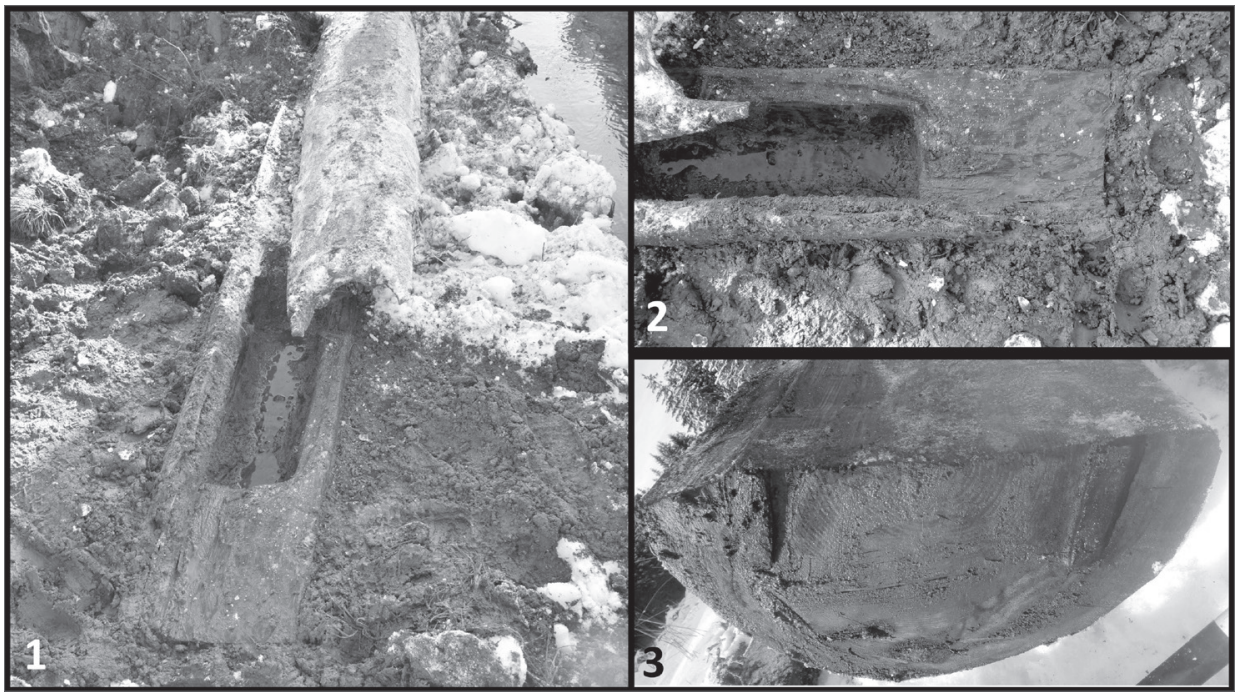

Obr. 10. Detail vypouštěcího systému rybníka Zweitämmige. 1 - situace po odkrytí bagrem; 2 - detail vypouštěcího koryta; 3 - detail na tzv. kramle, které držely obě poloviny výpusti dohromady. Foto archiv ÚAM FF MU.

Abb. 10. Detail des Auslasssystems des Teiches Zweitämmige. 1 - Situation nach Ausbaggerung; 2 - Detail der Auslassrinne; 3 - Detail der sog. Klammern, die beide Auslasshälften zusammenhielten. Foto Archiv Institut für Archäologie und Museologie der Phil. Fak. der Masaryk-Universität. 
V prostoru se ještě před zahájením stavby vyskytovalo mnoho prvků, které zde zanechali skauti, a to konstrukce dřevěné chaty, „lednice“ zahloubené do tělesa hráze a mostky. Jen některé zanechaly stopy v archeologickém záznamu. Je tedy archeologickým přínosem i toto zjištění, přestože se jedná o výrazně recentní aktivity a struktury. Př́i čištění záplavy pro RN U Malovaného mostku dále probíhaly prospekční práce. Při nich byly otevřeny tři sondy na základě signálu při prospekci prováděné detektorem kovů. Sondy Střenčí 1/19 a Střenčí 2/19 v západní části záplavy RN byly vyhloubeny pouze do rybničního sedimentu šedé jílové struktury. V nich byly nalezeny dva kusy podkov. Jedná se o celou podkovu (Z 2384; obr. 11) a opracované dřevo (Z 2385) v podobě úštěpů ze sondy 1 a ze sondy 2 pochází část podkovy (Z 2386; obr. 12). Obě podkovy zastupovaly typ a formu, které lze časově zařadit na přelom 13. a 14. století. Podkovy lze roztř́idit podle formování ozubů. Podle tř́dění R. Krajíce patří k tvarům $6 \mathrm{~b}$ (Z 2385) nebo 6d (Z 2386), př́ípadně Kaźmierczykovým typům VI/1-2 (Krajíc 2003, 103, obr. 95; Kaźmierczyk 1978, 156-157). Soubory podkov vhodné pro porovnání pocházejí z Bolkova, Božanov, Bradla u Hostinného, Cvilínku, Hradišt'ka u Davle, Rokštejna, Semonic, Sezimova Ústí a Veselí nad Moravou a ve všech př́ipadech se jedná o časový horizont průběhu druhé poloviny 13. století až počátku 14. století (Drnovský-Mazáčková-Šrámek 2019, 577-579, obr. 15-16; Hejna 1962, 459, obr. 3:1; 1974, obr. 13:14-16, 395, obr. 14:9; Hrubý a kol. 2012, 393, 395, obr. 91; Richter 1982, 166-167, obr. 113:2-3; Huml 1967, 15, tab. IV:3, 5; Krajíc 2003, 104-105; Žákovský 2015, 235-236, 14:a-e).

Na hraně litorální zóny na levém břehu bezejmenné vodoteče protékající Střenčím byla objevena keramika. Jednalo se o kvalitně pálenou keramiku do šedých tónů zařaditelnou do 15. století. Další keramické nálezy pocházely z tělesa hráze. Zde keramika představovala nejstarší horizont existence vesnice v první polovině 13. století. Keramika zdobená radélkem (obr. 13:1) s přidaným grafitem do hrčiny, pálená za nižších teplot a v důsledku toho méně kvalitně vypálená a podléhající výrazně abrazi pochází také z areálu vesnice. Její výskyt na hrázi, tedy na hutněné zemině, může dokládat antropogenní aktivity v původní inundaci Kněžského potoka.

Délka homogenní vypouklé čelní hráze je $126 \mathrm{~m}$, šířka u paty 9-11 m, šířka v koruně $3 \mathrm{~m}$ a výška 2,8-3 m. Rekonstruovaná rozloha a objem vodní plochy zaniklé nádrže činí $6421,3 \mathrm{~m}^{2}$ a $8730 \mathrm{~m}^{3}$ zadržené vody. Maximální hloubka dosahovala patrně kolem 1,5 m. Rybník

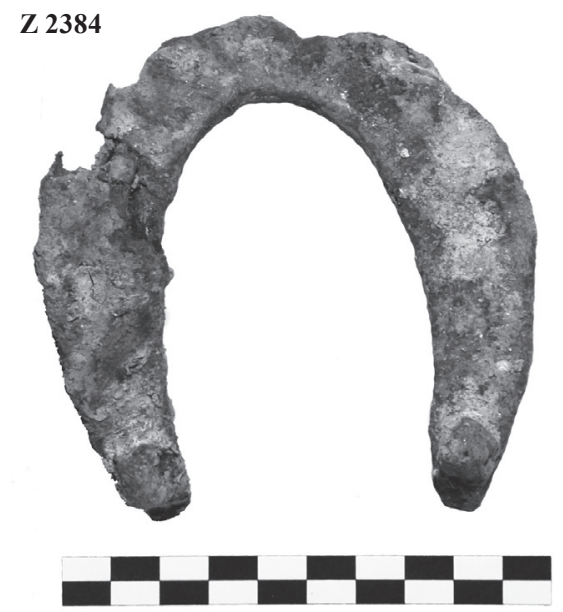

Obr. 11. Podkova Z 2384 ze sondy Střenčí 1/19. Foto archiv ÚAM FF MU.

Abb. 11. Hufeisen Z 2384 aus Sondierschnitt Střenčí 1/19. Foto Archiv Institut für Archäologie und Museologie der Phil. Fak. der Masaryk-Universität.

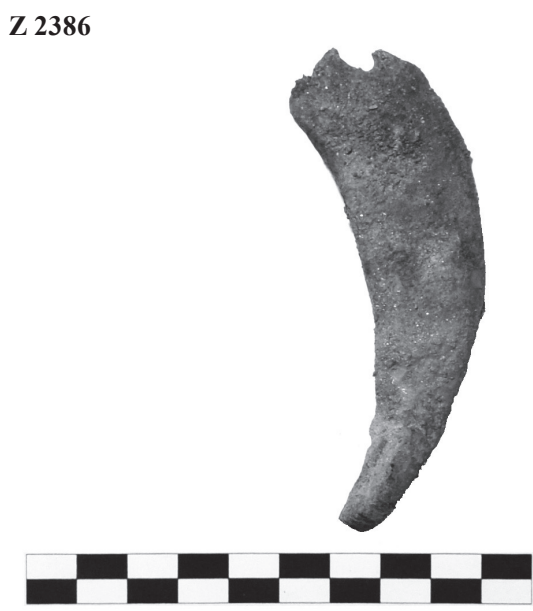

Obr. 12. Podkova Z 2386 ze sondy Střenčí 2/19. Foto archiv ÚAM FF MU.

Abb. 12. Hufeisen $Z 2386$ aus Sondierschnitt Střenčí 2/19. Foto Archiv Institut für Archäologie und Museologie der Phil. Fak. der Masaryk-Universität. 

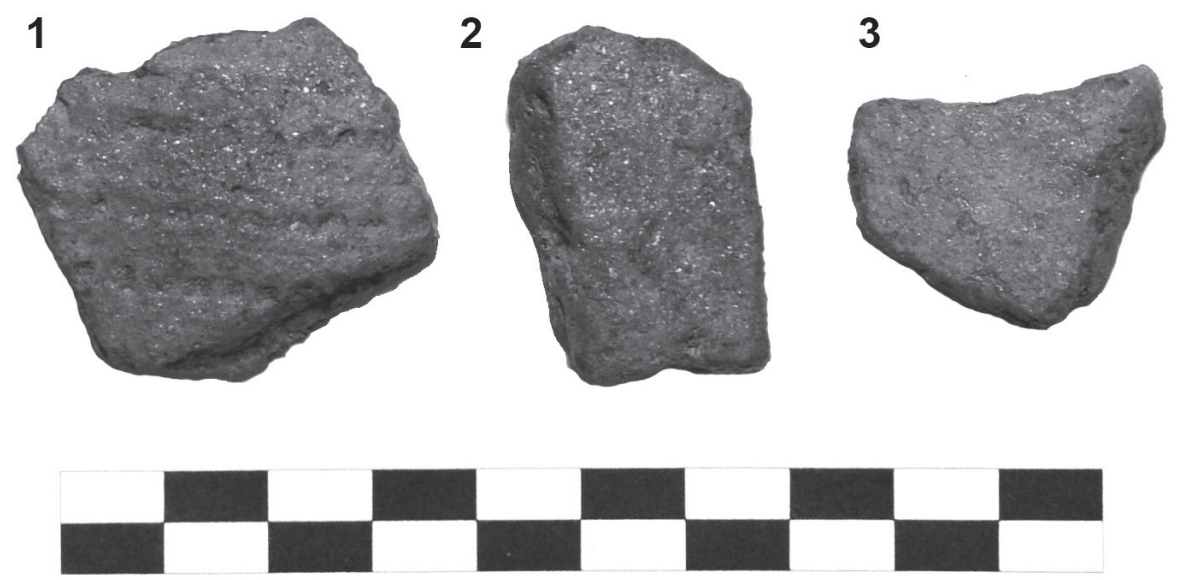

Obr. 13. Keramika získaná povrchovým sběrem z tělesa hráze - hrnčina s přidaným grafitem z první poloviny 13. století. 1 - fragment zdobený tzv. radélkem; 2-3 - nezdobené fragmenty. Foto archiv ÚAM FF MU.

Abb. 13. Durch Oberflächensammlung im Dammkörper entdeckte Keramik - Töpferware mit Graphitbeimengung aus der ersten Hälfte des 13. Jahrhunderts. 1 - Fragement mit sog. Rädchenverzierung; 2-3 - unverzierte Fragmente. Foto Archiv Institut für Archäologie und Museologie der Phil. Fak. der Masaryk-Universität.

leží v nadmořské výšce 587,1-589,8 m. Hráz svojí konstrukcí připomíná spíše Dubraviem popisované hráze než hráze Krčínovy. Poměr stran hráze podle Dubravia: výška hráze je totožná se šíŕkou v koruně hráze a šířka v patě hráze je trojnásobná vůči výšce hráze. Poměr návodní a vzdušné strany hráze je podle Dubravia 1 : 1, podle Krčína 1 : 1,5 (obr. 14). Rybník Zweitämmige měl hráz postavenou podle Dubraviem zapsaných norem ideální hráze v roce 1547.

Zatrubnění je zhotovené z jedlového dřeva datovaného smýcením k roku 1694/1695. Podle Dubravia - jak je uvedeno v díle De piscinis - je druhým nejvhodnějším dřevem pro zatrubnění výpusti rybníků po dubu právě jedle. „Druhé misto v délce snášení vlhkosti zaujímá jedle, a proto se po dubu nejvice voli na roury, které vkládáme do rybnični hráze, a stejně na výrobu zátky, kterou obecně nazýváme čepem, totiž na onen sloupek, který vyčnívá z roury a je vražen do jejího ústí, aby roura ani nenasávala, ani nepouštěla vodu bez naši vi̊le a svoleni" (Kyncl 2019; Dubravius 1559 , LIB.II, cap. 7, 49). Výpust i konstrukce hráze odpovídají obvyklým rybníkářským pravidlům stanoveným Dubraviem.

Rybník s hrází parc. č. 845 je v urbáři brtnického panství ještě v majetku Valdštejnů zmiňován v roce 1538, jeho starší existenci lze patrně doložit nepřítomností mladšího keramického materiálu na hrázním tělese, kde byl objeven pouze keramický materiál první poloviny 13. století. Pozdně středověké stáří je vysoce pravděpodobné. Novověkou existenci potvrzuje již zmíněný urbář k roku 1538, a na mladší collaltovské úpravy rybníků poukazuje dendrochronologické datování dřevěné roury výpusti (Kyncl 2019; Zaoralová 1988, 174-175).

Collaltovské hospodaření bylo doposud zpracováno z pohledu zemědělství, řemesel a zabrání poddanské zpustlé půdy v 60. a 70. letech 17 . století. K roku 1651 existují rybniční účty panství, které nebyly doposud podrobněji analyzovány. Mezi lety 1730-1740 byla sestavena kniha nařízení a instrukcí, která zahrnuje hospodaření s rybníky na panství Brtnice (Zaoralová 1988, 152, 165; MZA, fond F 16, inv. č. 122). Pozemkové knihy navazují na valdštejnské. Úřednický 
1

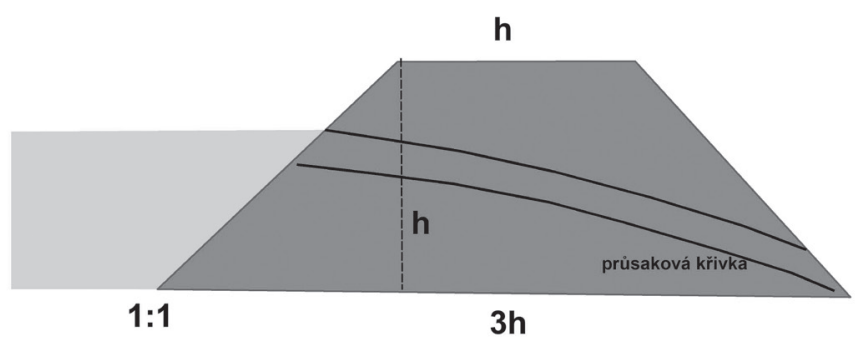

2

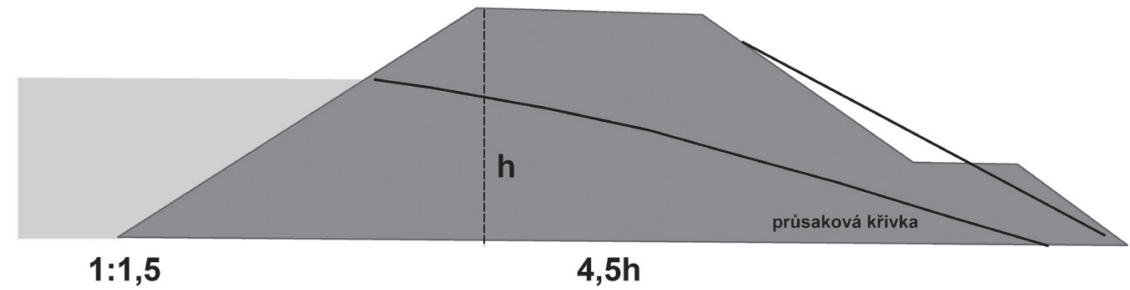

Obr. 14. 1 - hráz podle Dubravia; 2 - hráz podle Krěína. Podle Míka 1955, 37; Nový a kol. 1974, 366, 189a.

Abb. 14. 1 - Damm nach Dubravius; 2 - Damm nach Krčín. Nach Míka 1955, 37; Nový a kol. 1974, 366, 189a.

aparát brtnického panství zahrnoval vedle různých úředníků i porybného, který přímo spadal pod hejtmana a purkrabího panství a měl k ruce pacholky. Hejtman panství měl minimálně každé dva týdny obhlédnout majetky včetně rybníků (instrukce z roku 1667; Zaoralová 1988, 153). Rybniční podnikání se na panství Brtnice od počátku 18. století nevyplácelo, a tak došlo k vysoušení některých rybníků (Mlejnek 2008, 14-15).

Obdobná řešení výpusti rybníků jako v př́ípadě rybníka Zweitämmige se objevila u starších dřevěných výpustních konstrukcí s čapovým okem. Dřevěné roury jsou doložené v rybníce Jordán nebo Mirošov (Krajíc 2019, 1019; Petřík a kol. 2017, 804-805). Datování jedlové výpusti z rybníka Mirošov, který leží v prostoru bývalého broumovského panství, spadá k roku 1488/1489, dubová konstrukce k roku 1536/1537. Ve vzdálenosti 1-2 m od dřevěné výpusti a jejího čepového koryta č. 1 byla zachycena část dřevěného brlení (kaberny) původně tvořícího čtyřúhelník (Petřík a kol. 2017, 804-805, obr. 7). Jordánské dřevěné výpustní konstrukce, kde je doložen opět čapový druh výpusti včetně táhel, dokládají dobu založení rybníka (1492) i jeho následné opravy (Krajíc 2019, 1018-1019).

\section{Shrnutí}

Dochované výpustní zařízení rybníka Zweitämmige na Kněžickém potoce bylo zhotoveno krátce po roce 1694/1695. Souvisí s collatovským rybníkářstvím na panství a navazuje na starší valdštejnské rybniční aktivity. Rybník Zweitämmige a jeho 126 m dlouhá hráz odpovídá Dubraviovým rozměrům a jím uváděným délkovým nebo výškovým poměrům hrází (výška hráze je $3 \mathrm{~m}$ a její koruna má šířku $3 \mathrm{~m}$ ). Dřevěná výpust procházející tělesem hráze byla zhotovena z rozštípnutého kmene jedlového dřeva (skácení 1694/1695) a upravena pro čapové výpustní zařízení. Česlové stěny nebo také brlení nebylo v okolí výpusti zachyceno. Koryta dřevěné výpusti jsou spojena 
železnými dvojramennými skobami. Archeologický materiál pocházející z prospekce záplavového území RN U Malovaného mostku představují artefakty spojené s existencí vesnice, a to keramika a podkovy. Časové rozložení artefaktů je od první poloviny 13. století až do 15. století. Podkovy ze sond Střenčí 1/19 a Střenčí 2/19 spadají na přelom 13. a 14. století. Obě byly nalezeny v rybničním sedimentu. Př́ihodné geomorfologické podmínky v podobě poměrně širokých a mělkých uzavřených údolí na horních tocích s hustou sítí potoků představovaly nižší ekonomické náklady na výstavbu rybníků s vytvořením pouhé př̀hradní hráze (Matějek 1956, 45). Zároveň odpadla potřeba vybudovat přítokový systém k napájení nádrží. Tvar zkoumaného hrázního tělesa, které se v západní části hákovitě stáčí k ostrohu severního břehu bezejmenné střední vodoteče, napovídá, že se stavitel rybníku snažil o maximální zahrazení co největší plochy nádrže a zároveň o zabezpečení směrem ke vsi Střenčí. Rybník mohl souviset již s existencí vesnice Střenčí nebo vznikl při rybníkářském podnikání Valdštejnů. Hráz parc. č. 845 náleží k rybníku, který byl od raného novověku využíván pro svůj primární účel, jeho periodické využívání v řádu několika desetiletí je doloženo pro druhou polovinu 18. a průběh 19. století. Naposledy byl napuštěn s jistotou $\mathrm{v}$ roce 1856

\section{Prameny}

Moravský zemský archiv, fond G 10 Sbírka rukopisů zemského archivu, inv. č. 638 Urbář panství brtnického $\mathrm{z}$ doby před r. 1538 .

Moravský zemský archiv, fond F 16 Velkostatek Brtnice, mapy 1033, 1034, 1035, 1038, 1068, 1070, 1072, 1073.

Dubravius, I., 1559: De Piscinis et Piscium qui in eis aluntur naturis libri quinque.

\section{Edice pramenů}

CDM VII/1: Codex diplomaticus et epistlorais Moraviae VII/1 (Chytil, J., ed.). Brünn 1858.

KPb 1-6: Libri citationum et sententiarum seu. Knihy půhonné a nálezové 1-6 (Brandl, V., ed.). Brunae: Deputationis Marchonatus Moraviae 1872-1892.

ZDB I-XIV: Die Landtafel des Markgrathums Mähren. Brünner Cuda (Chlumecký P.-Chytil, J.-Demuth, C.-Wolfskron A. R., edd.). Brünn 1856.

ZDB XV-XXVIII: Moravské zemské desky II. 1480-1566. Kraj brněnský (Kalina, T., ed.). Praha 1950.

\section{Literatura}

DRNOVSKÝ, P.-MAZÁČKOVÁ, J.-ŠRÁMEK, J., 2019: Hrad u Božanova na Broumovsku a jeho možná úloha při stabilizaci broumovského klášterního dominia - Die Burg bei Božanov im Braunauer Ländchen und ihre mögliche Aufgabe bei der Stabilisierung des Klosterdominiums Braunau (Broumov), AH 44, 559-605. https://oi.org/10.5817/AH2019-2-4

HEJNA, A., 1962: Soubor nálezů z Hrádku u Bolkova v severovýchodních Čechách, PA LIII, 455-471.

- 1974: Bradlo u Hostinného nad Labem. Příspěvek k výzkumu opevněných sídel v severovýchodních Čechách, PA LXV, 365-418.

HRUBÝ, P. a kol., 2012: Středověký úpravnický a hornický areál Cvilínek u Černova na Pelhřimovsku, PA CIII, 339-418.

HRUBÝ, P. a kol., 2014: Centrální Českomoravská vrchovina na prahu vrcholného středověku. Brno.

HUML, V., 1967: Zaniklá tvrz Semonice. Fontes Musei Reginaehradensis - Supplementum II. Hradec Králové.

KAŹMIERCZYK, J., 1978: Podkowy na Śląsku w X-XIV wieku. Wrocław - Warszawa - Kraków - Gdańsk. 
KYNCL, T., 2019: ZAV U Malovaného mostku. Potrubí z hráze rybníku, Jestřebí u Brtnice. Nepublikovaná dendrochronologická zpráva. Brno.

KRAJÍC, R., 2003: Sezimovo Ústí. Archeologie středověkého poddanského města 3. Kovárna v Sezimově Ústí a analýza výrobků ze železa I, II. Praha - Sezimovo Ústí - Tábor.

- 2019: Středověké vodní dílo v Táboře. Archeologický výzkum Jordánu - Das mittelalerliche Wasserwerk in Tabor. Die archäologische Grabung am Jordan-Stausee, AH 44, 1001-1027.

MATĚJEK, F., 1954: Z feudální problematiky moravského předbělohorského období, ČMM LXXIII, 220-251.

- 1956: Přehled rozvoje rybníkářství na Moravě v 2. pol. 15. a v 1. pol. 16. století, ČSM V, 1956, 28-59.

MAZÁČKOVÁ, J., 2016: Středověká vesnice Českomoravské vrchoviny na př́kladu panství Rokštejn a Brtnice. In: Bajer, A.-Bíško, R.-Dejmal, M.-Hejhal, P.-Hrubý, P.-Lisá, L.-Machová, B.-Malý, K.-Mazáčková, J.-Plaček, M.-Šabatová, K.-Těsnohlídek, J.-Zimola, D.-Žahourková, A., Historická krajina Českomoravské vrchoviny. Osídlení od pravěku do sklonku stř̌edověku. Katalog k výstavě v Muzeu Vysočiny Jihlava, 89-116. Jihlava.

MĚŘÍNSKÝ, Z., 1988: Počátky osídlení Brtnicka a nejstarší dějiny obce. In: Dějiny Brtnice a připojených obcí (Janák, J. et al., edd.), 13-49. Brno - Brtnice.

MÍKA, A., 1955: Slavná minulost českého rybníkářství. Praha.

MLEJNEK, O., 2008: Panská Lhota v raném novověku. Brtnice - Brno.

NAVRÁTIL, V., 1985: Výstražný kamenný kříž v Jestřebském lese, VVM XXXVII, 82-85.

NOVÝ, R. a kol., 1974: Dějiny techniky v Československu (do konce 18. století). Praha.

PETŘÍK, J. kol., 2017: Rybník jako součást hospodářství vrchnostenského panství a indikátor podoby krajiny jižního Valašska v 15. až 17. století - Fischteiche als ökonomische Bestandteile einer adeligen Grundherrschaft und als Indikator für die Landschaftsform der Mährischen Südwalachei im 15. bis 17. Jahrhundert, AH 42, 789-817. https://doi.org/10.5817/AH2017-2-19

RICHTER, M., 1982: Hradišt'ko u Davle. Městečko ostrovského kláštera. Praha.

SLAVÍK, F. A., 1893: Zaniklé osady na panství brtnickém, ČMM XVII, 24-31.

ZAORALOVÁ, M., 1988: Období druhého nevolnictví 1648-1740. In: Dějiny Brtnice a připojených obcí (Janák, J. et al., edd.), 151-177. Brno - Brtnice.

ŽÁKOVSKÝ, P.-HOŠEK, J., 2015: Kovové artefakty. In: Veselí nad Moravou. Středověký hrad v říční nivě (Plaček, M.-Dejmal, M., edd.), 220-251. Brno.

\section{Internetové zdroje}

MZA - indikační skica. Dostupné z: http://www.mza.cz/indikacniskici/index.php\#show:MOR091118350.

\section{Zusammenfassung}

\section{Der Fischteich Zweitämmige in historischen und archäologischen Quellen}

In der Nähe der mittelalterlichen Dorfwüstung Střenčí wurde im Rahmen einer archäologischen Rettungsgrabung, die durch die in der historischen Landschaft Polesí Aleje (Katastergebiet Jestřebí u Brtnice) durchgeführte Raumplanung hervorgerufen wurde, auch das Relikt eines Dammes eines untergegangenen Wasserreservoirs untersucht. Die historischen und archäologischen Daten deuten auf eine langfristige Nutzung des Reservoirs hin, und zwar als Fischteich an einem örtlichen Wasserlauf, dem Bach Kněžický Potok. Die schriftlichen Quellen sprechen mit direktem Bezug auf die mittelalterliche Dorfwüstung Střenčí von Fischteichen (14.-15. Jahrhundert). Die Teichkaskade wurde offenbar zusammen mit der Dorfgründung als Bestandteil ihres direkten wirtschaftlichen Hinterlandes angelegt. Als Beispiel kann eine Aufzeichnung aus dem Jahr 1390 angeführt werden, als Albert von Zaharhany mit Albert von Mladyeyowicze 
Besitztümer im Dorf erwarben, zu denen gerade auch Fischteiche zählten. Das Dorf wird zuletzt im Jahr 1447 als besiedelt erwähnt. Danach finden das Dorf und seine Fischteiche im Urbarium des Pirnitzer Herrschaft aus dem Jahr 1538 Erwähnung, an dessen Ende sich auch ein Verzeichnis aller Fischteiche der Herrschaft Waldstein befindet. Dieses Verzeichnis deutet auf die Tatsache hin, dass die Fischteiche noch genutzt wurden, nachdem das Dorf selbst wüst wurde, was auch von jüngeren Kartenwerken belegt wird. Auf einer Karte aus dem Jahr 1822 kann der untersuchte Damm als Fischteich Zweitämmige identifiziert werden. Der dendrochronologisch datierte Auslass des Teiches (1694/1695) belegt lediglich eine langfristige Nutzung des Dammes und seine Instandhaltung. In Struktur und Abmessungen entspricht er den Beschreibungen, die von Dubravius im Jahr 1547 als ideale Entwürfe von Dammwerken aufgeführt werden. Den letzten Zeitabschnitt, in dem der Teich befüllt worden sein muss, können wir anhand der schriftlichen Quellen und Kartenunterlagen in das Jahr 1856 datieren.

Mgr. Jana Mazáčková, Ph.D., Ústav archeologie a muzeologie Filozofické fakulty Masarykovy univerzity, Arna Nováka 1, 60200 Brno, Česká republika,jkrejsov@phil.muni.cz, ORCID 0000-0002-2379-2990

Mgr. Petr Žaža, Ústav archeologie a muzeologie Filozofické fakulty Masarykovy univerzity, Arna Nováka 1, 60200 Brno, Česká republika, petrzaza@mail.muni.cz, ORCID 0000-0003-3405-2899 